Разин Анатолий Федорович, $\partial-p$ экон. наук, главный научный сотрудник, Всероссийский научно-исследовательский институт овощеводства - филиал ФГБНУ «Федеральный научный центр овощеводства». Россия.
140153, Московская обл., Раменский р-н, д. Верея, стр. 500. Тел.: (496) 462-43-64.

Ключевые слова: Anethum graveolens L.; архитектоника семенного растения; структура семян; семя; эндосперм; зародыш.

\title{
LINEAR PARAMETRES OF MORPHOLOGICAL ELEMENTS OF DILL SEEDS AS INDICATORS OF HETEROGENEITY
}

Bukharov Alexander, doctor of agricultural sciences, chief resBukharov Alexander Phedorovich, Doctor of Agricultural Sciences, Chief Re-searcher, All-Russian Scientific Research Institute of Vegetable Growing - a branch of the Federal Budget Scientific Institution "Federal Scientific Center for Vegetable Growing". Russia.

Baleev Dmitry Nikolaevich, Candidate of Agricultural Sciences, Senior Re-searcher, All-Russian Scientific Research Institute of Vegetable Growing - a branch of the Federal Budget Scientific Institution "Federal Scientific Center for Vegetable Growing”. Russia.

Ivanova Maria Ivanovna, Doctor of Agricultural Sciences, Professor of RAS, Chief Researcher, All-Russian Scientific Research Institute of Vegetable Growing - a branch of the Federal Budget Scientific Institution "Federal Scientific Center for Vegetable Growing”. Russia.

Buharova Almira Rakhmetovna, Doctor of Agricultural Sciences, Professor, Rus-sian State Agrarian Extramural University. Russia.

Fefelov Fedor Olegovich, Candidate of Agricultural Sciences, Senior Researcher, All-Russian Scientific Research Institute of Vegetable Growing - a branch of the Federal Budget Scientific Institution "Federal Scientific Center for Vegetable Growing". Russia.

Razin Oleg Anatolyevich, Candidate of Agricultural Sciences, Leading Researcher, Federal State Scientific Institution "Federal Research Center of Horticulture". Russia.

Razin Anatoly Fedorovich, Doctor of Economics, Senior Researcher, All-Russian Scientific Research Institute of Vegetable
Growing - a branch of the Federal Budg-et Scientific Institution "Federal Scientific Center for Vegetable Growing”. Russia.

Keywords: Anethum graveolens L.; architectonics of seed plants; semen structure; seed; endosperm; germ.

The influence of the location of the umbel of dill (Centaurus variety) (Anethum graveolens L.) on the linear parameters of the seed was investigated. It was revealed that the average values of the dill seed length $(3.85-3.43 \mathrm{~mm})$, endosperm (3.37-2.99 $\mathrm{mm}$ ) and the embryo (1.00-0.77 $\mathrm{mm}$ ) varied significantly. Quality dif-ferences in the parameters of the morphological elements of the seed depended on both the architectonics of the seed plant and environmental conditions. The en-dosperm length averaged 88-89\% of the seed length. The length of the embryo in the primary inflorescences was $26 \%$ of the length of the seed and $30 \%$ of the length of the endosperm; in secondary umbel - by 5 and $6 \%$ lower. The length of the seed and endosperm was mainly influenced by the environmental factor $(P<0.001)$, and the length of the embryo by the matric factor $(P<0.001)$. Correlation analysis showed that the effect of seed length on the length of the endosperm had a high positive dependence $(r=0.961-0.978)$. There is a weak correlation between the length of the embryo and the length of the seed, as well as between the length of the embryo and the length of the endosperm $(r=0.050-0.314$ and 0.066-0.325, respectively).

\section{ОПТИМИЗАЦИЯ РАЦИОНОВ КОРМЛЕНИЯ МОЛОДНЯКА СВИНЕЙ В УСЛОВИЯХ РЕСПУБЛИКИ МОРДОВИИ}

\author{
ГУРЬЯНОВ Александр Михайлович, Мордовский НИИСХ - филиал ФГБНУ ФАНЦ Северо- \\ Востока
}

кокОРЕВ Виктор Александрович, Мордовский НИИСХ - филиал ФГБНУ ФАНЦ СевероВостока

ПЕТУНЕНКОВ Сергей Владимирович, Мордовский НИИСХ - филиал ФГБНУ ФАНЦ СевероВостока

БОРИН Александр Васильевич, Мордовский НИИСХ - филиал ФГБНУ ФАНЦ Северо-Востока

Проведено сравнение эффективности использования для поросят-сосунов и отъемышей до достижения 4-месячного возраста специализированных комбикормов. В их составе установлено влияние биоактивных добавок селацида и крезацина на продуктивность молодняка; выявлены оптимальные дозы ввода в состав комбикорма. Установлено последствие спецкомбикормов и изучаемых добавок на энергию роста молодняка свиней с 5- до 8-месячного возраста. К кониу откорма животных среднесуточный прирост по сравнению с контрольной группой был выше во 2-й опытной группе - на 4,5 \%, в 3-й - на 8,8 \%, в 4-й - на 13,9\% и в 5-й - на 1,2\%. При этом скороспелость свиней составила соответственно, дней: 230, 221, 211,203 и 227. Использование в кормлении поросят в раннем возрасте разработанных спецкомбикормов позволяет в последующем существенно повысить энергию роста и скороспелость откормочных свиней.

Введение. Рациональное научно обоснованное кормление животных возможно только при условии глубокого знания их потребностей в энергии, питательных и биологически активных веществах и их варьирования, в зависимости от внешних и внутренних факторов. Трансформация корма, особенно кормового протеина, в полезную для человека продукцию в организме свиньи с возрастом уменьшается. Поэтому, чтобы сократить затраты кормов на производство свинины, требуется нарастить максимально возможную 
массу животных в молодом возрасте [1, 2, 4,15, 16].

Органические соединения кормов, находясь в сложной биохимической форме, в пищеварительном тракте животных подвергаются механическому и многоступенчатому ферментативному воздействию и расщепляются до простых соединений, способных легко проникать через стенки кишечника в кровеносную систему, разноситься по организму и участвовать в обмене веществ. При этом часть из них не поддается преобразованию и выделяется с калом. Поэтому важным резервом увеличения продуктивности является улучшение усвоения питательных веществ используемых кормов, которое зависит от индивидуальных особенностей животных и подготовки кормов к скармливанию, типа и структуры рациона, уровня и соотношения элементов питания, наличия биологическиактивных и минеральных веществ [6, 7, 13, 14].

Отдельные виды кормов, входящие в состав рационов, обычно имеют дефицит необходимых элементов питания для животного. При смешивании этих кормов в различных комбинациях и соотношениях получаются полноценные кормовые смеси [5]. Отсюда, успешное развитие свиноводства немыслимо без производства полнорационных комбикормов. В этой связи вопросы питания поросят-сосунов и поросят-отъемышей должны быть предметом особого внимания. Сбалансированное кормление поросят-сосунов и поросят раннего отъема в период интенсивного роста и развития обеспечивает максимальные приросты при наименьших затратах кормов. При полноценном кормлении поросят используются специальные стартерные комбикорма, достаточное потребление которых способствует стимуляции синтеза и активности пищеварительных энзимов и секреторной деятельности желудочнокишечного тракта, формированию и стабилизации нормальной кишечной микрофлоры и, как следствие, лучшей интенсивности роста и сохранности молодняка $[8-11,17]$.

Для повышения эффективности отрасли необходимо пересматривать существующие рецепты стандартных комбикормов, совершенствовать систему питания поросят с использованием различных биологически активных добавок. За последние годы широкое применение в питании молодняка животных в раннем возрасте получили такие добавки, как селацид и крезацин. Селацид обладает уникальным избирательным действием в кишечнике при высоких значениях $\mathrm{pH}$, угнетает рост патогенных бактерий, улучшает всасывающую способность кишечника поросят. Это сильный подкислитель кормов, в состав которого входят муравьиная, сорбиновая, уксусная, 11 лимонная, молочная, пропионовая кислоты. и уменьшает затраты на лечение, обеспечивает безопасное развитие животных. Крезацин состоит из органической соли триэтаноламина и крезоксиуксуснойкислоты, защищаетклеткисердца от повреждения окисляющими токсинами, в том числе нитратами и нитритами, снижает вязкость крови, уменьшает воспалительные процессы, вероятность образования тромбов в сосудах, повышает антиоксидантные свойства и иммунитет организма. На практике крезацин используют для стимулирования роста и развития животных, сохранности плода и жизнестойкости потомства, улучшения качества продукции животноводства $[3,5,12,16]$.

Цель данной работы - определение эффективности скармливания биоактивных добавок селацида и крезацина и их влияния на продуктивность молодняка, установление оптимальных доз для ввода в состав стартерных комбикормов.

Методика исследований. В Мордовском НИИСХ были проведены два научно-хозяйственных и физиологический опыты на поросятах крупной белой породы от рождения до 4 месяцев и с 5- до 8-месячного возраста, а также производственная апробация стартерных комбикормов с включением в их состав изучаемых кормовых добавок.

Научно-хозяйственный опыт проводили на пяти группах поросят, подобранных по принципу аналогов по 20 голов каждый. В 1-й контрольной группе животные получали стартерные комбикорма. Во 2-й опытной группе скармливали стартерные комбикорма с включением крезацина. В 3-й опытной группе вносили в комбикорм крезацин и селацид одновременно в дозе, рекомендованной производителями. В 4-й группе количество добавок уменьшили от нормы на 30 \%, а в 5-й группе доза была на 30 \% увеличена (табл. 1).

В Мордовском НИИСХ разработаны рецепты стартерных комбикормов для поросят от рождения до 4месяцев и с 5- до 8-месячного возраста, изучено их влияние на продуктивность и здоровье молодняка. На основе выявленного дефицита элементов питания в кормах созданы рецепты стартерных комбикормов (табл. 2).

Результаты исследований. Чтобы говорить о росте и развитии подопытных животных под воздействием стартерных комбикормов с разным количеством селацида и крезацина, изучали характерные показатели (табл. 3). Анализ этих показателей выявил, что животные опытных групп отличались относительно высокой энергией роста. Так, к концу опыта наибольшая живая масса была у поросят 4-й опытной группы, получавших с комбикормами повышенную на 30 \% норму крезацина и селацида, и составила 47,90 кг, что выше, чем у аналогов контрольной группы, на 8,64 кг (22 \%), во 2, 3 и 5-й опытных группах соответственно на 6,25 кг $(15,0 \%), 2,45$ кг (5,4\%) и 7,27 кг (17,9\%), P>0,001. Следует отметить, что норма ввода добавок, рекомендуемая производителями, также позволила к концу опыта получить животных в 3-й опытной группе с высокой живой массой (45,45 кг), что выше по сравнению с 1-й контрольной группой на $15,7 \%$, 2-й опытной - на 9,1 \%, 5-й опытной - на $11,8 \%$.

В одно- и двухмесячном возрасте среднесуточный прирост поросят 3-й группы составил 258 и 378 г, что выше, чем у аналогов 4-й группы, соответственно на 2,5 и 1,5 \%. Но в три и четыре месяца этот показатель в 4-й группе составил 442 и 511 г, что 
Схема скармливания кормовых добавок (второй научно-хозяйственный опыт)

\begin{tabular}{|c|c|c|c|c|c|c|c|c|c|c|}
\hline \multirow{2}{*}{ Группа } & \multirow{2}{*}{$\begin{array}{c}\text { Особенности } \\
\text { кормления }\end{array}$} & \multicolumn{9}{|c|}{ Возраст, дней } \\
\hline & & $6-15$ & $16-30$ & $31-45$ & $46-60$ & $61-65$ & $66-75$ & $76-90$ & $91-105$ & $106-120$ \\
\hline 1-я & \multicolumn{10}{|c|}{ Стартерные комбикорма } \\
\hline $2-я$ & $\begin{array}{l}\text { Комбикорм + } \\
+ \text { крезацин, г }\end{array}$ & 0,007 & 0,030 & 0,065 & 0,095 & 0,127 & 0,132 & 0,148 & 0,159 & 0,176 \\
\hline $3-9$ & $\begin{array}{c}\text { Комбикорм + } \\
+ \text { селацид }+ \\
+ \text { крезацин, г } \\
\end{array}$ & $\begin{array}{l}0,490 \\
0,007 \\
\end{array}$ & $\begin{array}{l}2,100 \\
0,030 \\
\end{array}$ & $\begin{array}{l}4,550 \\
0,065 \\
\end{array}$ & $\begin{array}{l}6,650 \\
0,095 \\
\end{array}$ & $\begin{array}{l}6,000 \\
0,127 \\
\end{array}$ & $\begin{array}{l}6,000 \\
0,132 \\
\end{array}$ & $\begin{array}{l}6,750 \\
0,148 \\
\end{array}$ & $\begin{array}{l}7,250 \\
0,159 \\
\end{array}$ & $\begin{array}{l}8,000 \\
0,176 \\
\end{array}$ \\
\hline $4-9$ & $\begin{array}{c}\text { Комбикорм + } \\
+ \text { селацид }(+30 \%)+ \\
+ \text { крезацин }(+30 \%), \text { г }\end{array}$ & $\begin{array}{l}0,637 \\
0,009 \\
\end{array}$ & $\begin{array}{l}2,730 \\
0,039 \\
\end{array}$ & $\begin{array}{l}5,915 \\
0,085 \\
\end{array}$ & $\begin{array}{l}8,645 \\
0,124 \\
\end{array}$ & $\begin{array}{l}7,800 \\
0,165 \\
\end{array}$ & $\begin{array}{l}7,800 \\
0,172 \\
\end{array}$ & $\begin{array}{l}8,775 \\
0,193 \\
\end{array}$ & $\begin{array}{l}9,425 \\
0,207 \\
\end{array}$ & $\begin{array}{c}10,400 \\
0,229 \\
\end{array}$ \\
\hline 5-я & $\begin{array}{c}\text { Комбикорм + } \\
+ \text { селацид }(-30 \%), \Gamma+ \\
+ \text { крезацин }(-30 \%), \text { г } \\
\end{array}$ & $\begin{array}{l}0,343 \\
0,005 \\
\end{array}$ & $\begin{array}{l}1,470 \\
0,023 \\
\end{array}$ & $\begin{array}{l}3,185 \\
0,050 \\
\end{array}$ & $\begin{array}{l}4,655 \\
0,073 \\
\end{array}$ & $\begin{array}{l}4,200 \\
0,098 \\
\end{array}$ & $\begin{array}{l}4,200 \\
0,102 \\
\end{array}$ & $\begin{array}{l}4,725 \\
0,114 \\
\end{array}$ & $\begin{array}{l}5,075 \\
0,123 \\
\end{array}$ & $\begin{array}{l}5,600 \\
0,135 \\
\end{array}$ \\
\hline
\end{tabular}

Таблица 2

Состав стартерных комбикормов для поросят, \% по массе

\begin{tabular}{|c|c|c|}
\hline \multirow[b]{2}{*}{ Ингредиенты } & \multicolumn{2}{|c|}{ Комбикорм } \\
\hline & $\begin{array}{l}\text { престартер (от рождения } \\
\text { до 2-месячного возраста) }\end{array}$ & $\begin{array}{c}\text { стартер (от 2- до 4-месячного } \\
\text { возраста) }\end{array}$ \\
\hline Кукуруза & 10 & 5 \\
\hline Отруби & 9 & 10 \\
\hline Ячмень & - & 30,3 \\
\hline Экструдированный ячмень & 20 & 10 \\
\hline Пшеница & 14 & 20 \\
\hline Ячмень без пленки & 15,2 & - \\
\hline Шрот соевый & 6 & 2 \\
\hline Шрот подсолнечный & 4 & 8 \\
\hline Дрожжи кормовые & 4 & 3 \\
\hline Рыбная мука & 5 & 3 \\
\hline $30 \mathrm{OM}$ & 8 & $\frac{3}{4}$ \\
\hline Жир сухой кормовой & 2 & 1,5 \\
\hline Мука известняковая & 1,0 & 1,0 \\
\hline Монокальций фосфат & 0,5 & 0,85 \\
\hline Соль поваренная & 0,3 & 0,35 \\
\hline Премикс П 51-1 & 1,0 & 1,0 \\
\hline
\end{tabular}

выше, чем у сверстников из 5, 3 и 2-й опытных групп, а также контрольной группы соответственно на 23,8 и $31,4 \%, 8,6$ и $13,1 \% ; 18,9$ и $26,4 \%$, на 28,8 и $34,4 \%$. В среднем за опыт поросята 4-й опытной группы получили среднесуточный прирост 402,2 г, что выше по сравнению с аналогами из других групп, соответственно на 22,9; 15,6; 5,64 и 18,7 \%.

Понижение на 30 \% крезацина и селацида в составе комбикормов не оказало существенного влияния на повышение энергии роста опытных животных 5-й группы, где среднесуточный прирост за весь опыт составил 338,6 г, что ниже, чем у поросят 2-й опытной группы, получавших стартерные комбикорма с включением только крезацина, на 2,7 \%; в 3-й и 4-й группах на 11,0 \% и $15,8 \%$ соответственно.

Использование стартерных комбикормов с включением 5 мг/кг живой массы крезацина во 2-й опытной группе позволило получить от каждого животного 39,6 кг абсолютного прироста живой массы, что выше по сравнению с 1-й контрольной и 5-й опытной группами соответственно на 6,3 и

\section{Динамика живой массы и среднесуточных приростов}

\begin{tabular}{|c|c|c|c|}
\hline Группа & Возраст, мес. & Живая масса, кг & Среднесуточный прирост, г \\
\hline \multirow{5}{*}{$1-я$} & 6 дней & $1,98 \pm 0,04$ & \\
\hline & 1 & $7,62 \pm 0,16$ & $235,00 \pm 6,23$ \\
\hline & 2 & $17,55 \pm 0,34$ & $331,00 \pm 5,74$ \\
\hline & 3 & $27,85 \pm 0,48$ & $343,33 \pm 5,12$ \\
\hline & 4 & $39,26 \pm 0,59$ & $380,33 \pm 3,76$ \\
\hline \multirow{5}{*}{2 -я } & 6 дней & $2,00 \pm 0,06$ & \\
\hline & 1 & $7,95 \pm 0,16$ & $247,91 \pm 5,19$ \\
\hline & 2 & $18,36 \pm 0,29$ & $345,00 \pm 5,22$ \\
\hline & 3 & $29,52 \pm 0,50$ & $372,00 \pm 6,68$ \\
\hline & 4 & $41,65 \pm 0,71$ & $404,30 \pm 8,05$ \\
\hline \multirow{5}{*}{$3-9$} & 6 дней & $2,05 \pm 0,06$ & \\
\hline & 1 & $8,26 \pm 0,15$ & $258,75 \pm 4,54$ \\
\hline & 2 & $19,62 \pm 0,35$ & $378,66 \pm 6,82$ \\
\hline & 3 & $31,89 \pm 0,56$ & $407,00 \pm 8,50$ \\
\hline & 4 & $45,45 \pm 0,49$ & $452,00 \pm 6,17$ \\
\hline \multirow{5}{*}{ 4-я } & 6 дней & $2,04 \pm 0,08$ & \\
\hline & 1 & $8,10 \pm 0,15$ & $252,50 \pm 4,63$ \\
\hline & 2 & $19,29 \pm 0,34$ & $373,00 \pm 5,22$ \\
\hline & 3 & $32,56 \pm 0,47$ & $442,33 \pm 5,36$ \\
\hline & 4 & $47,90 \pm 0,68$ & $511,30 \pm 7,05$ \\
\hline \multirow{5}{*}{ 5-я } & 6 дней & $2,02 \pm 0,05$ & \\
\hline & 1 & $7,86 \pm 0,14$ & $243,30 \pm 4,43$ \\
\hline & 2 & $18,24 \pm 0,36$ & $346,00 \pm 6,54$ \\
\hline & 3 & $28,96 \pm 0,47$ & $357,30 \pm 4,48$ \\
\hline & 4 & $40,63 \pm 0,66$ & $389,00 \pm 7,15$ \\
\hline 1-я & \multirow{4}{*}{ В среднем за опыт } & & 327,01 \\
\hline $2-9$ & & & 347,80 \\
\hline $3-9$ & & & 380,70 \\
\hline 4-я & & & 402,20 \\
\hline 5-9 & & & 338,60 \\
\hline
\end{tabular}


$2,7 \%(P>0,05)$, но на 8,6 и 13,5 \% $(P>0,001)$ ниже по сравнению с аналогами 3-й и 4-й опытных групп. Дополнительное включение в комбикорм поросятам 3-й опытной группы крезацина 5 мг/кг живой массы и селацида 7 кг/т комбикорма до 60-дневного и 5 кг/т с 60- до 120-дневного возраста позволило получить 43,4 кг дополнительного прироста живой массы, что на 16,4 и 12,4 \% $(P>0,001)$ выше по сравнению с 1-й контрольной и 5-й опытной группами, но ниже, чем уаналогов 4-й группы, на 5,4\% $(P>0,01)$. Снижение в комбикорме уровня кормовых добавок на 30 \% в 5-й группе привело к снижению абсолютного прироста по сравнению с животными 4-й группы на 15,8 \%, хотя данный показатель был выше на 3,5 \% по сравнению с аналогами 1-й контрольной группы. С возрастом у свиней относительная скорость роста снижалась с 117-120 до 33-38 \% (табл. 4). У животных 3-й и 4-й групп на протяжении всего периода отмечали наиболее высокую энергию роста (120-35 и $119-38 \%)$.

От рождения до 30-дневного возраста более интенсивно росли поросята 3 -й опытной группы $(120,6 \%)$, а с $30-$ до 60-дневного возраста напряженность роста животных в 3-й и 4-й опытных группах была на одном уровне $(81,5-81,7 \%)$. С 60- до 120-дневного возраста данный показатель был выше у животных 4-й опытной группы (38,151,2 \%) по сравнению с 3-й группой на 3,1-3,8 \%.

Для дальнейшего изучения степени влияния стартерных комбикормов и кормовых добавок, используемых при выращивании поросят до конца 4-месячного возраста, на их последующую продуктивность с 5 до 8 месяцев был проведен научно-хозяйственный опыт. На основе выявленного дефицита элементов питания в кормах разработали рецепты белково-витаминноминеральных концентратов (БВМК) для баланса рационов молодняка свиней до норм РАСХН 2003 г. (табл. 5).

Животным, которыеучаствовали в данном опыте, скармливали комбикорм собственного производства: ячмень 64,0 \% + пшеница 23,5 \% + БВМК 12,5\%.

Данные табл. 6 показали, что смещение активной фазы роста в период доращивания в 4-й опытной группе способствовало дальнейшему повышению энергии роста животных. Это позволило получить 623 г среднесуточного прироста с 5- до 6-месячного возраста и 635 г - с 6- до 8-месячного возраста, что соответственно выше, чем в 5-й группе, - на 11,1 и $14,1 \%$; в 3-й - на 4,6 и 4,7 \%; во 2-й - на 7,6 и 10,4 \% и контрольной - на 10,3 и 17,6 \%. Следует отметить, что молодняк всех опытных групп, получавший до 4-месячного возраста стартерные комбикорма с кормовыми добавками, отличался в последующем высокой продуктивностью.

Так, с5- до 8-месячного возраста среднесуточный прирост во 2-й опытной группе был выше по сравнению с контрольной группой на 4,5 \%, в 3-й на $8,8 \%$, в 4-й - на $13,9 \%$, в 5-й - на $1,2 \%$. Это позволило получить к 8-месячному возрасту во 2-й опытной группе животных с живой массой 110,7 кг, в 3, 4 и 5-й группах соответственно 117,4, 123,2 и 107,3 кг, что на $5,2(P<0,001) ; 11,9(P<0,001) ; 17,7$ и 1,8 кг $(P<0,001)$ дополнительного прироста больше, чем в 1-й контрольной группе.

Высокая энергия роста способствовала достижению 100 кг живой массы в 1-й контрольной группе за 230 дней, во 2-й опытной группе - за 221 день, в 3-йза 211 дней, в 4-й - за 203 дня и в пятой - за 227 дней.

Заключение. Включение крезацина 0,100 г/кг комбикорма до 60-дневного возраста и 0,110 г/кг комбикорма с 60- до 120-дневного возраста и селацида соответственно 7 и 5 г/кг комбикорма способствовало смещению активного периода роста в сторону раннего возраста в подсосный период. Повышение добавок на 30 \% усиливало напряженность роста поросят в послеотъемный период.

Скармливание поросятам стартерных комбикормов с включением кормовых добавок по-

Абсолютная и относительная скорость роста опытных животных

\begin{tabular}{|c|c|c|c|}
\hline \multirow{2}{*}{ Группа } & \multirow{2}{*}{ Возраст, мес. } & \multicolumn{2}{|c|}{ Прирост } \\
\hline & & абсолютный, кг & относительный, \% (по Броди С.) \\
\hline \multirow{5}{*}{$1-я$} & 6 дней & - & - \\
\hline & 1 & $5,64 \pm 0,15$ & 117,5 \\
\hline & 2 & $9,93 \pm 0,19$ & 78,9 \\
\hline & 3 & $10,30 \pm 0,16$ & 45,3 \\
\hline & 4 & $11,41 \pm 0,12$ & 34,0 \\
\hline \multirow{5}{*}{2} & 6 дней & - & - \\
\hline & 1 & $5,95 \pm 0,15$ & 119,7 \\
\hline & 2 & $10,35 \pm 0,16$ & 78,7 \\
\hline & 3 & $11,16 \pm 0,21$ & 46,6 \\
\hline & 4 & $12,13 \pm 0,24$ & 34,1 \\
\hline \multirow{5}{*}{ 3-я } & 6 дней & - & - \\
\hline & 1 & $6,21 \pm 0,10$ & 120,6 \\
\hline & 2 & $11,36 \pm 0,21$ & 81,5 \\
\hline & 3 & $12,21 \pm 0,28$ & 47,4 \\
\hline & 4 & $13,56 \pm 0,18$ & 35,0 \\
\hline \multirow{5}{*}{ 4-я } & 6 дней & - & - \\
\hline & 1 & $6,06 \pm 0,12$ & 119,5 \\
\hline & 2 & $11,19 \pm 0,16$ & 81,7 \\
\hline & 3 & $13,27 \pm 0,15$ & 51,2 \\
\hline & 4 & $15,34 \pm 0,21$ & 38,1 \\
\hline \multirow{5}{*}{$5-9$} & 6 дней & - & - \\
\hline & 1 & $5,84 \pm 0,11$ & 118,2 \\
\hline & 2 & $10,38 \pm 0,17$ & 79,5 \\
\hline & 3 & $10,72 \pm 0,15$ & 45,4 \\
\hline & 4 & $11,67 \pm 0,23$ & 33,5 \\
\hline $1-9$ & \multirow{5}{*}{ За весь опыт } & 37,28 & \\
\hline $2-9$ & & 39,65 & \\
\hline $3-9$ & & 43,40 & \\
\hline $4-9$ & & 45,86 & \\
\hline $5-9$ & & 38,61 & \\
\hline
\end{tabular}


Достижение науки и техники АПК. - 2006. - № 3. -

\section{Состав БВМК для молодняка свиней, \% по массе}

\begin{tabular}{|c|c|c|}
\hline \multirow{2}{*}{ Ингредиенты } & \multicolumn{2}{|c|}{ Откормочный молодняк } \\
\hline & І период & II период \\
\hline Шрот подсолнечный & 18 & 22,5 \\
\hline Шрот соевый & 12 & 15 \\
\hline Кормовые дрожжи & 25 & 23 \\
\hline Рыбная мука & 10 & 9 \\
\hline Кровяная мука & 8 & 6 \\
\hline $30 \mathrm{M}$ & 3 & - \\
\hline Мука известковая & 8 & 9 \\
\hline Монокальций фосфат & 10 & 9,5 \\
\hline Соль поваренная & 4,8 & 4,9 \\
\hline Лизин & 0,2 & 0,1 \\
\hline Премикс 1\% - П 55-2 & 1 & - \\
\hline Премикс $1 \%$ - П 55-3 & - & 1 \\
\hline \multicolumn{3}{|c|}{ В 1 кг БВМК содержится: } \\
\hline кормовых единиц & 0,92 & 0,9 \\
\hline обменной энергии, МДж & 12 & 11,5 \\
\hline сухого вещества, кг & 0,9 & 0,9 \\
\hline сырого протеина, г & 380 & 370 \\
\hline переваримого протеина, г & 328 & 322 \\
\hline сырого жира, г & 34 & 32 \\
\hline сырой клетчатки, г & 40 & 68 \\
\hline лизина, г & 28 & 24 \\
\hline метионина + цистина, г & 5 & 5 \\
\hline кальция, г & 61 & 60 \\
\hline фосфора, г & 35 & 34 \\
\hline натрия, Г & 21,8 & 27 \\
\hline калия, г & 16,2 & 17 \\
\hline железа, мг & 375 & 346 \\
\hline меди, мг & 66 & 76 \\
\hline цинка, мг & 338 & 342 \\
\hline марганца, мг & 165 & 206 \\
\hline кобальта, мг & 9,7 & 10,3 \\
\hline йода, мг & 0,4 & 0,6 \\
\hline селена, мг & 1,5 & 1,5 \\
\hline витаминов: А, тыс., МЕ & 26,2 & 25,5 \\
\hline Д, тыс., ME & 2,6 & 2,5 \\
\hline Е, мг & 72 & 75 \\
\hline $\mathrm{B}_{2}, \mathrm{M \Gamma}$ & 16,5 & 17 \\
\hline $\mathrm{B}_{3}, \mathrm{M \Gamma}$ & 45 & 43 \\
\hline $\mathrm{B}_{4}, \mathrm{M \Gamma}$ & 1500 & 1450 \\
\hline $\mathrm{B}_{5}, \mathrm{M \Gamma}$ & 27 & 86 \\
\hline $\mathrm{B}_{6}, \mathrm{M \Gamma}$ & 16 & 16 \\
\hline $\mathrm{B}_{12}, \mathrm{M \Gamma}$ & 0,21 & 0,20 \\
\hline
\end{tabular}

ложительно повлияло на энергию роста в период с четырех до восьми месяцев. Это, возможно, объясняется усилением обменных процессов и улучшением использования питательных веществ рационов для жизнедеятельности организма и роста тканей.

\section{СПИСОК ЛИТЕРАТУРЫ}

1. Васильев А.А., Коробов А.П. Влияние стартового комбикорма на мясную продуктивность поросят // Мясная индустрия. - 2006. - № 6. - С. 52.

2. Гурьянов А.М., Кяшкин А.В., Петуненков С.В. Эффективность скармливания молодняку свиней стартерного комбикорма с кормовыми добавками //

\section{С. 26-27.}

3. Гурьянов А.М. Микроминеральное питание свиней. - Саранск, 2007. - 401 с.

4. Гурьянов А.М., Артемьев А.А. Основы рационального использования фуражного зерна в животноводстве // Достижение науки и техники АПК. - 2008. № $6 .-$ С. $52-55$.

5. Кокорев В.А., Гурьянов А.М., Громова Е.В. Новое в микроминеральном питании растущих свиней // Актуальные проблемы производства свинины в Российской Федерации: материалы Всерос. науч.-произв. конф. Саратов: КУБ и К, 2011. - С. 79-82.

6. Кокорев В.А., Гурьянов А.М. Микроминеральное питание свиней // Современные проблемы и научное обеспечение инновационного развития свиноводства: материалы XXIII Междунар. науч.-практ. конф., 21-23 июня 2016, Московская обл., пос. Лесные Поляны. - пос. Лесные Поляны: ФГБГУ ВНИИплем, 2016. - 322 с.

7. Кокорев В.А., Гурьянов А.М. Современные нормы микроминерального питания растущих свиней // Современные технологии в животноводстве: проблемы и пути их решения: материалы Междунар. науч.-практ. конф. - Мичуринск, 2017. - С. 16-27.

8. Коробов А.П., Васильев А.А., Москаленко С.П. Стартерные комбикорма в рационе поросят-сосунов // Свиноводство. - 2000. - № 4. - С. 11-13.

9. Коробов А.П., Васильев А.А., Кубайтов Н.С. Стартерный комбикорм - путь повышения продуктивности свиней // Свиноводство. - 2001. - № 2. C. $20-21$.

10. Коробов А.П., Васильев А.А. Стартерный комбикорм экономически выгоден // Животноводство России. - 2005. - № 2. - С. 28.

11. Коробов А.П., Васильев А.А. Эффективность использования стартерного комбикорма в кормлении поросят-сосунов // Доклады Российской академии сельскохозяйственных наук. - 2001. - № 3. C. $43-44$.

12. Нормы и рационы кормления сельскохозяйственных животных: справочное пособие / под. ред. А.П. Калашникова [и др.]. - М., 2003. - 456 с.

13. Понаморенко Ю.А., Фисинин В.И., Егоров И.А. Безопасность кормов, кормовых добавок и продуктов питания. - Минск: Эко-перспектива, 2012. - 861 с.

14. Рекомендации по использованию комплекса микроэлементов в кормлении подсвинков / И.В. Зирук [и др.]. - Саратов, 2014. - 32 с.

15. Смирнов В.В., Васильев А.А., Москаленко С.П. Эффективность использования препарата «Био Актив» в рационах свиноматок и поросят-отъемышей // Аграрный

Таблица 6

\section{Динамика живой массы с 5- до 8-месячного возраста}

\begin{tabular}{|c|c|c|c|c|}
\hline Группа & Возраст, мес. & Живая масса, кг & Среднесуточный прирост, г & Скороспелость, дней \\
\hline \multirow{4}{*}{ 1-я } & 5 & $39,20 \pm 0,59$ & - & \multirow{4}{*}{230} \\
\hline & 6 & $73,10 \pm 0,60$ & $565,0 \pm 4,5$ & \\
\hline & 8 & $105,5 \pm 0,94$ & $540,0 \pm 6,6$ & \\
\hline & В среднем & & 552.5 & \\
\hline \multirow{4}{*}{ 2-я } & 5 & $41,45 \pm 0,73$ & - & \multirow{4}{*}{221} \\
\hline & 6 & $76,20 \pm 0,57$ & $579,2 \pm 7,2$ & \\
\hline & 8 & $110,70 \pm 0,74$ & $575,0 \pm 7,0$ & \\
\hline & В среднем & & 577,1 & \\
\hline \multirow{4}{*}{ 3-я } & 5 & $45,25 \pm 0,47$ & - & \multirow{4}{*}{211} \\
\hline & 6 & $81,00 \pm 0,76$ & $595,8 \pm 6,3$ & \\
\hline & 8 & $117,40 \pm 0,87$ & $606,7 \pm 6,1$ & \\
\hline & В среднем & & 601,3 & \\
\hline \multirow{4}{*}{ 4-я } & 5 & $47,70 \pm 0,66$ & - & \multirow{4}{*}{203} \\
\hline & 6 & $85,10 \pm 0,86$ & $623,3 \pm 5,7$ & \\
\hline & 8 & $123,20 \pm 0,97$ & $635,0 \pm 5,6$ & \\
\hline & В среднем & & 629,2 & \\
\hline \multirow{4}{*}{ 5-я } & 5 & $40,23 \pm 0,67$ & - & \multirow{4}{*}{227} \\
\hline & 6 & $73,90 \pm 0,93$ & $561,2 \pm 5,7$ & \\
\hline & 8 & $107,30 \pm 0,96$ & $556,7 \pm 5,1$ & \\
\hline & В среднем & & 558,9 & \\
\hline
\end{tabular}


научный журнал. - 2017. - № 5. - С. 41-45.

16. Эффективность использования ростостимулирующего препарата и спецкомбикормов в рационах молодняка свиней / А.M. Гурьянов [и др.] // Актуальные проблемы производства свинины в Российской Федерации: материалы Всерос. науч.-произв. конф. - Саратов: КУБ и К, 2011. - C. 34-36.

17. Korobov A.P., Vasilev A.A. Effect of feeding starter mixed feed to suckling pigs on their reproductive qualities // Russian Agricultural Sciences, 2010, T. 36, No. 2, P. 122-124.

Исследования выполнены в рамках тематическо$2 о$ плана НИР Мордовского НИИСХ - филиала ФГБНУ ФАНЦ Северо-Востока.

Гурьянов Александр Михайлович, $\partial-p$ c.-х. наук, проф., гл. научный сотрудник, Мордовский НИИСХ - филиал ФГБНУ
ФАНЦ Северо-Востока. Россия.

Кокорев Виктор Александрович, $\partial-p$ c.- $x$. наук, проф., старший научный сотрудник, Мордовский НИИСХ - филиал ФГБНУ ФАНЦ Северо-Востока. Россия.

Петуненков Сергей Владимирович, канд. с.-х. наук, старший научный сотрудник, Мордовский НИИСХ - филиал ФГБНУ ФАНЦ Северо-Востока. Россия.

Борин Александр Васильевич, канд. с.-х. наук, старший научный сотрудник, Мордовский НИИСХ - филиал ФГБНУ ФАНЦ Северо-Востока. Россия.

430904, Республика Мордовия, г. Саранск, р.п. Ялга, ул. Мичурина, 5.

Тел.: (88342) 25-36-85;e-mail: niish-mordovia@mail.ru.

Ключевые слова: кормление; рацион; свиньи; концентраты; комбикорм; кормовые добавки; премикс; живая масса; прирост; эффективность.

\title{
OPTIMIZATION OF RATIONS OF YOUNG PIGS FEEDING IN CONDITIONS OF THE REPUBLIC OF MORDOVIA
}

Guryanov Alexander Mikhailovich, Doctor of Agricultural Sciences, Professor, Chief Researcher, Mordovia Research Agricultural Institute - Branch of the FARC North-East. Russia.

Kokorev Victor Aleksandrovich, Doctor of Agricultural Sciences, Professor, Sen-ior Researcher, Mordovia Research Agricultural Institute - Branch of the FARC North-East. Russia.

Petunenkov Sergey Vladimirovich, Candidate of Agricultural Sciences, Senior Researcher, Mordovia Research Agricultural Institute - Branch of the FARC North-East. Russia.

Borin Alexander Vasilievich, Candidate of Agricultural Sciences, Senior Researcher, Mordovia Research Agricultural Institute - Branch of the FARC North-East. Russia.

Keywords: feeding; ration; pigs; concentrates; mixed fodder; feed additives; premix; live weight; increment; efficiency.

The studies were carried out in the Mordovia Research Institute for the purpose of comparing the efficiency of the use of specialized mixed fodders for suckling pigs and weaners until the age of 4 months. In their composition, the effect of bioactive additions of selacide and krezacin on the productivity of young animals was tested, their optimal dose of feed intake was determined. The effect of special feeds and the studied additives on the growth energy of young pigs from 5 to 8 months of age has been established. By the end of fattening animals daily gain compared to the control group it was higher in the second experimental group - by $4.5 \%$, third - $8.8 \%$ and $13.9 \%$ at the fourth and in the fifth to $1.2 \%$. The early ripeness of the control group pigs was 230 days, the second - 221, the third - 211, the fourth - 203 and the fifth - 227 days. Hence, the use of the developed special feed in the feeding of piglets at an early age makes it possible in the future to substantially increase the energy of growth and early maturity of fattening pigs.

\section{КАЛЮЖНЫЙ Иван Исаевич, Саратовский государственный аграрный университет имени}

\author{
Н.И. Вавилова
}

ДЭНС-терапия была применена на 56 телятах, заболевиих бронхопневмонией, в возрасте от раннего неонатального до шести месящев. Контроль эффективности лечения осуществляли клинически, фиксируя характер физикальных изменений уживотных в течение двухнедельного курса и привесы. Частичное улучшение клинического состояния телят наблюдалосъ уже после трех дней аппликаций электродов аппарата «ДиаДЭНС-ПК» На триггерные биологически активные точки. Существенное улучшение симптоматики у телят наступало к 5-7-му дню. На более ранних сроках уменъиилсь проявления общего интоксикационного синдрома, купировались физикальные симптомы бронхопневмонии. Исполъзование данной схемы лечения увеличило прирост массы тела животных по группам от 432 до 600 2. Эффективность лечебных мероприятий составила 93,36\%.

Введение. Бронхопневмония неинфекционной этиологии у молодняка крупного рогатого скота одна из актуальных ветеринарных проблем в силу большого удельного веса в патологии скота и риска развития тяжелых осложнений $[1,3,6]$. Высокий уровень заболеваемости животных бронхопневмонией сохраняется в настоящее время среди всех возрастных групп телят, придавая проблеме терапии и профилактики особую значимость и актуальность [3, $4,8]$. Один из способов лечения телят при неспеци- фической бронхопневмонии - использование немедикаментозных средств, в частности физиотерапевтических методов $[2,9,10]$. Существует потребность во внедрении их в клиническую практику.

Все чаще в поле зрения ветеринарных специалистов попадает метод чрезкожной динамической электронейростимуляции - ДЭНСтерапия. Она применяется в медицинской лечебно-профилактической практике с 2001 г. Суть ее заключаетсяв воздействиина определенныеактивные 